\title{
GCU
}

Glasgow Caledonian

University

University for the Common Good

\section{Payment for offsite goods and materials: the Scottish perspective}

Morrison, Siobhan; Trushell, lan

Published in:

Construction Management and Economics

DOI:

10.1080/01446193.2016.1200738

Publication date:

2016

Document Version

Author accepted manuscript

Link to publication in ResearchOnline

Citation for published version (Harvard):

Morrison, S \& Trushell, I 2016, 'Payment for offsite goods and materials: the Scottish perspective', Construction Management and Economics, vol. 34, no. 10, pp. 679-687. https://doi.org/10.1080/01446193.2016.1200738

\section{General rights}

Copyright and moral rights for the publications made accessible in the public portal are retained by the authors and/or other copyright owners and it is a condition of accessing publications that users recognise and abide by the legal requirements associated with these rights.

Take down policy

If you believe that this document breaches copyright please view our takedown policy at https://edshare.gcu.ac.uk/id/eprint/5179 for details of how to contact us. 


\section{PAYMENT FOR OFFSITE GOODS AND MATERIALS: THE SCOTTISH PERSPECTIVE}

\section{Siobhan Morrison and Dr.I Trushell}

Materials are a critical element within the construction industry yet- the conditions and legality surrounding their ownership remains an area of uncertainty. The difficulty in ascertaining ownership is often found in the instances of payment, delivery and complex contractual relationships. Additionally, the nature of the construction industry whereby raw materials are purchased within a supply chain and are incorporated into the fabric of buildings or goods often creates further confusion. The importance of ownership is most apparent in the instance of disputes or insolvencies, both of which are regular occurrences within the construction industry and in the management of a project regarding cashflow and programme. To inform the position and stance of Scots Law in relation to ownership of materials it is necessary to evaluate current law regarding ownership of materials in Scotland through the undertaking of a literature review which establishes the prevailing legal structure. Conclusions and recommendations propose that parties of a construction contract, for which Scots Law is applicable, are aware of current law surrounding the intricate matter regarding ownership of materials in Scots Law.

Keywords: contract law, insolvency law, liquidation, materials, ownership, payment, sale of goods, Scotland. 


\section{Introduction}

Materials are the fundamental ingredient to a construction project. However, ascertaining who holds ownership of materials can be decidedly difficult within the numerous and complex contractual arrangements of the construction industry. Construction projects are a multidisciplinary process due to the nature of the 'product' and industry as a whole. One single project can involve many disciplines and the creation of several interfaces between each of the parties involved, resulting in a complex supply chain and the development of many contractual relationships. The importance of contractual relationships is crucial when asserting the rights attached to each party to administer the contracts effectively and in resolving disputes, should they arise. Disputes are recognised as a consistent and regular occurrence within the construction sector, arising from numerous and varied situations. Research by Malleson (2013) reveals there is a market trend which indicates the level of disputes has increased over the last few years and both industry bodies and disciplines believe construction disputes will continue to increase. The litigious atmosphere of the construction industry is magnified in times of decreased availability of work due to an unstable economic climate. As a consequence of the recent economic situation, a number of firms had entered into insolvency proceedings and members of the construction industry are continuing to protect themselves against the risks associated with liquidation. Beale and Mitchell (2009) confirm that insolvency is a prominent and threatening occurrence within the present day construction sector and advise it is imperative that those involved within a project protect themselves regarding the payment and ownership of materials.

Additionally, payment of materials has a direct effect upon cashflow within a project. Cashflow is paramount in construction projects and is frequently documented as being directly linked to delayed programmes, having an impact upon project delivery and 
contributing to a deterioration in working relationships. A reduction in cashflow for any one project also has an effect on other projects the Contractor may have running concurrently within his business. The certainty of payment for materials is therefore of crucial concern for cashflow purposes and overall management of a project and a business.

The legal conditions surrounding payment of materials is determined by a number of factors. Variables include the wording of the contract, whether the materials are located on or off site, fixed or unfixed to the works, and both when possession and ownership of property is transferred and who retains that ownership at the various stages of the process. The determination of these points differs dependent on the legal perspective and structure prevalent within the country where work is taking place. The intricate details and legal requirements regarding ownership of materials is one such matter whereby the legal difference between English and Scots Law becomes apparent. Thus, construction works are not only accountable to a contract but also to the common law and system in place within the country and transactions must adhere to the relevant protocols and legislation.

A 'black book' desk study approach will consist of a literature review of case and statutory law to establish the existing legal structure and law pertaining to ownership of materials within the Scottish legal context, with reference made to how this differs from English law. Legal transcripts and court judgements are a reliable, systematic and factually accurate source, and as such, are referred to in order to demonstrate the scenarios in which ownership will present and manifest itself and to ascertain who, at any given time, has property in the materials.

With consideration to the foregoing, the often contentious subject area concerning ownership of materials will be established within the legal context of Scotland with an aim to evaluate current Scots law practice and the differences from English law. 


\section{Scots Law and Contracts}

Scots Law is fundamentally derived and deduced from the laws and doctrines of ancient Rome. The legal structure within Scotland is of a deductive nature based upon the institutional writers who adopted Roman law which Walker (1989) identifies as being constituted of three separate principles; the laws of persons, things and actions. In contrast with Scots Law, is the inductive legal system practiced within England whereby case law and judgements accumulated over many years form a chain of judicial precedents which determine current practice, largely based upon the most recent of court decisions.

Upon identifying the overarching legal system, the particular category of law in which construction activities are undertaken is subject to further investigation. For instance, Public Law and Private Law are stipulated as two separate branches of law within the Scotland Act 1998 (MacQueen \& Thomson, 2012). Private Law incorporates, amongst other occurrences, the laws of unilateral promise and obligation. Construction contracts are associated with the law of obligations as they constitute an agreement whereby one party makes an offer and the other accepts for the achievement of a predetermined goal through actions or deeds performed by a member to the contract.

Incidentally, 'construction contracts,' is a recognised statutory term as a consequence of the UK issued Housing Grants, Construction and Regeneration Act 1996 which defines a construction contract within Section 104(1) as 'an agreement with a person for ...the carrying out of construction operations.' Historically, the Act only applied to construction contracts in writing, not to a building contract which could be oral, however, this is superseded by the 2011 amendments to the Act which encompass applicability of construction contracts regardless of whether they are oral or in writing. The Act encompasses both the hire and sale aspects and nature of the industry through utilising the term 'construction operations' and 
proceeding to define operations to include for the hire of services, such as a consultant for surveying or design works, which extends to any documentation they may prepare. Therefore, a construction contract within Scotland is subject to comply with the Scottish common law, i.e. with the current Scottish legislation and the Scottish case law.

\section{Contracts of Hire, Contracts of Sale and Contracts of Sale and Hire}

The distinction and difference established between 'things' and 'actions,' or correspondingly, sale and hire within Roman Law was reflected in the practice of separate contracts for each component, which Connolly (1999) argues becomes problematic within the context of building or construction works, as it poses the question of whether the contract will be a contract of hire, purchase and sale, or both.

When considering a contract of hire within the context of Roman times, there was traditionally a different contract for each of the three instances that could occur in construction; the hire of property to be used by another, the hire of labour or the leasing of property to allow for work either to it or on it. Connolly (1999) proposes that within these classifications a building contract could be categorised as either the second or third option. It is upon this ideology that modern day contracts are founded.

A contract of sale relates to the purchase of goods and is regulated by the Sale of Goods Act 1979, a UK parliament Act, amended and updated from the original 1893 legislation (Uff, 2013). Section 2 (1) of the Act defines a sale of goods as 'A contract by which the seller transfers or agrees to transfer the property in goods to the buyer.'

Interestingly, this definition does not specify payment or delivery as determined factors that would constitute a sale. The implied notion is that of intention, whereby the seller 'agrees to transfer the property.' Also notable within this condition is the absence of any services; the contract is purely for the sole purpose of the purchase and sale of goods. 
The separation of contracts of hire and sale does not explicitly accommodate for all possible transactions that could occur, for example, a contract of hire may result in the production of 'goods' yet a contract of sale may not have necessarily occurred. An attempt to remedy this situation was made with the introduction of the Supply of Goods and Services Act 1982 and Scots Law was further accommodated for by the Sale and Supply of Goods Act 1994 which contained provisions for matters relating to the Scottish legal system. This legislation is applicable to building contracts due to the varying scenarios that can occur regarding hire and sale, as Atiyah, et al., (2005) suggest, the relevant Act to each country applies irrespective of whether services are provided or otherwise within a contract.

\section{Payment, Delivery and Intention}

Evidentially, the intricate nature of construction contracts in Scotland as a developed form of Roman principles is distinctive in respect of hire and sale, however, there is historically an absence of particulars relating to the ownership of materials. The question of whether ownership and title to materials passes upon payment, delivery or intention is a matter in which much deliberation is present, yet which can only be ascertained by thoroughly investigating each circumstance.

Regarding payment, Hughes, et al., (2015) inform that the general consensus at common law is that ownership of materials transfers to the Employer when materials are incorporated into the works, whether or not payment has taken place. As this matter is complicated by the varied contractual relationships within the construction industry, it is prudent to establish the relationship and whether payment within the supply chain alters, or indeed constitutes, the transfer of ownership.

The complication of ownership with regards to delivery is dependent on the type of contract used. A contract of sale, or supply only contract, would allow for property in goods to pass 
upon delivery, however, the nature of a construction contract is not that of only sale. The combined hire, or supply of services creates an effect in which delivery alone cannot allow transfer of ownership within Scots Law, contrary to the legal position in England. The matter is demonstrated within the Scottish judicial precedent of Seath \& Co v. Moore [1886] $13 R$ 57 HL, incidentally prior to the Sale of Goods Act 1893, in which Lord Watson stated;

Materials provided by the builder...although intended to be used in the execution of the contract, cannot be regarded as appropriated to the contract or as 'sold' unless they have been affixed to or in a reasonable sense made part of the corpus...

Evidently, this case displays that sale and hire must both be considered complete to allow for the transfer of ownership. The ruling indicates that in addition to delivery, there is a condition that labour and incorporation of the materials must have taken place. This sentiment is echoed by the statement of Bell (1899) that '...the articles sent are merely the materials, the act of delivery seems not to complete till the work be performed'. Bell re-affirms and elaborates on the 'act of delivery' to specify that delivery in itself is not complete until work has been carried out.

With respect to intention, Section 6, 11B (1) of the Supply of Goods and Services Act 1982 introduced implied terms to facilitate the right to transfer title; 'In a contract for the transfer of goods...there is an implied term on the part of the transferor that...he has a right to transfer the property.' This condition reinforces the terms expressed within the Sale of Goods Act 1979 which specified the seller 'agrees' to transfer title, thus supporting the notion of intention and agreement to transfer.

Additionally, the Supply of Goods and Services Act 1982 also implied a term to allow for 'quiet possession of goods,' in Section 12, 2B, whereby the Purchaser, or Employer, is legally 
permitted to possess the goods without interference from other parties, including claims for ownership.

\section{Contractual Relationships and Transfer of Ownership}

The contractual relationships effective within a project play a vital role in ascertaining who owns title in goods and subsequently who, therefore, has the authority to transfer those goods. Furst \& Ramsey (2015) highlight that the industry consists of numerous disciplines and in the traditional structure of a project there is an Employer, Contractor and one or more Subcontractors. Any or all of the parties mentioned can be involved in further relationships with Suppliers. Bowles \& Gow (1992) repeat the same and progress to explain that law recognises the difference between the role of a Sub-contractor, who provides both goods and labour, and a Supplier, who supplies only goods.

This complex supply chain creates numerous contractual relationships where parties are not necessarily in direct contract with one another. Within construction contracts, it is regular practice that Employers and Sub-contractors have no contractual relationship. There is a danger or risk attached when parties are not in direct contract with one another as Hughes, et al., (2015) explain that historically, the law doctrine concerning Privity of Contract would not allow a third party with no contractual relationship to enforce contract terms. The Contract (Rights of Third Parties) Act 1999 has sought to remedy the situation and covers England, Wales and Northern Ireland. The Act does not apply within Scotland, the equivalent remedy is a derivation of the law doctrine 'jus quaesitum tertio,' whereby Collateral Warranties are used for third party rights.

The traditional Employer and Contractor relationship typically involves the Employer engaging with the Contractor to carry out the works inclusive of supply. This relationship is, in effect, relatively straight forward. The Employer can also enter into a contract of purchase 
and sale with a Supplier for an item to be incorporated into the works and contract another party to install or incorporate that item. A Contractor can then in turn procure either; the services of a sub-contractor, supply of materials and services from a sub-contractor, or the supply of goods from a Supplier. The distinction between each of these roles and relationships is crucial when deliberating who rightfully holds ownership to materials. Adriaanse (2010) considers that issues regarding ownership of materials are most likely to arise in the relationships Contractors have with Sub-contractors and Suppliers. He proposes the difficulty predominantly lies within the likelihood that the Contractor does not acquire the right to the goods which lawfully prohibits him in turn to sell on to a third party, e.g., the Employer. Failure to obtain ownership is a circumstance known as the 'nemo date' rule which Adriaanse (2010) explains means that 'a person cannot give better title than he or she has.'

In the event of a contractor purchasing goods from a Supplier, Section 25 of the Sale of Goods Act 1979 states ownership rights to the goods are specified to have passed;

Where a person having agreed to buy goods obtains, with the permission of the seller, possession of the goods...the delivery and transfer by that person... of the goods...receiving the same in good faith...right of the original seller of the goods.

Transfer of ownership is conditional upon 'good faith' and there can be no reproach on the basis of a retention of title clause.

Successful application Section 25 is demonstrated in the Scottish case of Archivent Sales \& Developments Ltd v Strathclyde Regional Council [1985] SLT 154. Strathclyde Regional Council had employed R.D. Robertson (Builders) Ltd as the Contractor for the construction of a school. Robertson had engaged in a supply-only contract with Archivent for the purchase of multiple ventilators which contained a retention of title clause stipulating that property in 
the goods would not pass to the customer until payment had been received in full. Robertson took possession of the goods which had been delivered to site by Archivent. Strathclyde Council certified and made payment to Robertson for the goods, unaware of any title reservation clause. In accordance with their contract, payments for materials within an interim certificate become property of the Employer. Robertson received payment from Strathclyde Council but did not pay Archivent for the supply of the ventilators before going into receivership. Archivent, the Supplier, requested return of the materials, or payment, from Strathclyde Council. Presiding Lord Mayfield held that in terms of the contract between the Supplier and Contractor, the intention for ownership to pass was upon payment in accordance with a sale of goods contract. However, the possession of the materials by the Contractor, who acted as a 'mercantile agent' not out with the regular and accepted practice of construction transactions and subsequent delivery to the Employer, was evidence enough to satisfy that ownership had transferred to Strathclyde Council.

Section 25 of the Sale of Goods Act 1979 prevailed over a retention of title clause in this instance and as had occurred previously in the Scots Law case of Thomas Graham \& Sons Ltd v Glenrothes Development Corporation [1968] SLT 2. Lord Mayfield's judgement made much reference to this case and of particular interest was Lord President Clyde's statement declaring;

Section 25 is a statutory recognition of an exception to the general rule that only an owner of goods can transfer the property in them. The section enables an apparent owner to transfer someone else's goods to a third party in certain specific circumstances.

This statement highlights that the Sale of Goods Act 1979 acknowledges there may be substantial reasoning in favour of the third party for ownership to transfer depending on the particulars of the case. The nature of some transactions, such as those performed in 
construction, allows an agent to effectively assume ownership thus enabling them to transfer the title of those goods.

The outlined cases demonstrate instances of insolvency and the importance of ascertaining who holds ownership to materials if a party becomes insolvent. MacQueen \& Thomson (2012) define insolvency as 'the inability to meet obligations as they fall due because total liabilities exceed total assets.' This definition encompasses the various different forms of insolvency; administration, receivership and liquidation, which are all subject to the Insolvency Act 1986. Essentially, a company or person is insolvent if they are unable to finance their obligations and there are also repercussions for parties they are involved with as found in the case of Archivent Sales \& Developments Ltd v Strathclyde Regional Council [1985]. Insolvency of a party within a construction contract often presents specific and complex issues, therefore, Totty, et al., (2014) advise of the importance and criticality of being fully aware and informed of the current law procedures and their applicability to the particular construction contract and events within any given case. Watt (2010) reaffirms that when Liquidators become involved, recovery of goods or money becomes challenging and exceedingly unlikely.

\section{Circumstances of Materials}

In addition to the complexities surrounding contractual relationships, a further consideration is the circumstances in which an ownership dispute is occurring, i.e. whether the goods or materials supplied have been transformed or incorporated into the works or where they are located or stored at the time their ownership is debated.

Materials that have been incorporated into the fabric of the building under both English and Scots Law are considered property of the Employer and ownership is deemed to have 
transferred. Payment for the materials need not have taken place as Watt (2010) confirms that incorporation regardless of payment is sufficient for ownership to transfer.

\section{Materials On Site}

In the event that materials are on site but have not yet been incorporated into the works, the situation becomes more complex and requires further investigation to determine whether ownership has indeed passed from a Supplier or Sub-Contractor to the Contractor or Employer, or whether it has been retained.

As demonstrated in the cases of Archivent Sales v Strathclyde Regional Council [1985] and Thomas Graham \& Sons Ltd v Glenrothes Development Corporation [1968], a Supplier is unable to claim ownership of the materials if those materials have been included within an interim payment certificate. In the event of a Contractor's insolvency and in spite of a reservation of title clause, the Supplier will have no claim for unfixed materials on site if they have been included within main contract payments. Brewer (2004) advises that in this situation the Supplier or Subcontractor remain very much 'at risk for the value' of those unfixed materials which have been paid under the Employer and Contractor main contract, yet no payment has been received by those bearing the risk.

Contrary to the aforementioned cases, an important decision in England which illustrates the differences between English and Scots Law, took place in the case of Dawber Williamson Roofing Ltd v Humberside County Council [1979] 14 BLR 70. The decision resulted in amendments to the Joint Contracts Tribunal (JCT) standard forms of contract to provide security for Employers in disputes regarding ownership of materials. A supply and fix contract existed between the subcontractor Dawber Williamson Roofing and Taylor and Coulbeck, the Contractor, who were employed by Humberside County Council. Dawber Williamson had been prevented from commencing works as the project was behind schedule, 
but nonetheless Dawber supplied and delivered to site the roofing slates required in preparation to begin. Taylor and Coulbeck applied and received payment for the roofing slates from Humberside Council prior to their liquidation, although Dawber had not received any payment for the materials they had supplied. Upon knowledge of Coulbecks' liquidation, Dawber sought to retrieve the slates from the site, from which Humberside refused them access on the argument that the slates were now their property following their inclusion in the interim payment certificate of the main contract. Dawber maintained that the supply and fix contract did not entail 'selling' the materials to the contractor, and until they had been fixed to the structure and paid for, then ownership remained with them. Humberside relied on the defence that the main contract terms were incorporated into the subcontract.

It was held that the nemo date rule applied in this case as the contractor could not transfer property of the materials to Humberside Council as they had never acquired title in the first instance and secondly, Humberside's argument regarding the main contract terms becoming effective within the subcontract were insufficient as there was no privity of contract established between Dawber and Humberside (Furmston, 2012). Dawber were successful within this landmark case in English Law which instigated amendments to JCT standard forms of contracts to provide a level of security for Employers who, as Bowles \& Gow (1992) explain, would otherwise bear the risk for materials that they had paid for, but which had not yet been incorporated into the works. The revised terms stated that once materials or goods are delivered to site by a Subcontractor and included within the main contract interim certificates, the Subcontractor shall not 'deny that good title has passed to the employer' (Brewer, 2004). 


\section{Materials Off Site}

When materials are located off site on premises not belonging to the Employer, common law in Scotland dictates that property to the materials will not have passed. Stirling County Council v Official Liquidator of John Frame Ltd [1951] SLT 37 is the leading and most prominent case which expressly determined Scots Law regarding this scenario.

John Frame Ltd were employed by Stirling Council for construction works in a housing scheme. Due to limited space on site Frame stored, with the knowledge and permission of Stirling Council and their Architect, materials in a locked storage container in their yard, off site. Upon Frame's liquidation, Stirling Council attempted to retrieve the materials on the basis that Condition 5 of their contract expressed that 'From the time they are placed upon the site...all materials delivered by the Contractor for the execution of the works, shall become and be the absolute property of the Employer.'

Sheriff-Substitute Walker held that a building contract was not one of sale, and consequently, the title of the goods had not passed in this instance. With regards to Condition 5, he declared it was not enforceable and was in his opinion 'remarkable' and 'under reference to some foreign system of law, 'to which the legal system of England is the supposed inference. $\mathrm{He}$ further added it was 'conclusive' that Condition 5 was not applicable and furthermore, that Stirling County Council had not acquired any title to the materials.

Upon appeal, the Sheriff-Principal Black agreed the contract was not one of sale and disputed the pursuer's argument that the materials were 'constructively on site' to establish that there are two distinct stages which must be adhered to in order for property of the material to transfer. These stages consist of possession by placing materials on the site and delivery by incorporation into the works. He proceeded to explain that in storing the materials off site, they were subject to the control of the Contractor and could not be considered as being 
'delivered for the execution of the works' in any manner. The Sheriff-Principal was very much in agreement with the Sheriff-Substitute in all matters concerning this case which was in favour of the Frame Liquidators. The Employer and pursuant, Stirling County Council, were unsuccessful and did not receive recompense upon the Contractor's insolvency for materials paid for and located off site on the basis that delivery to site had not taken place.

This case was significant within Scots Law regarding payment for materials off site and caused the Royal Institution of Chartered Surveyors Scotland to advise this issue to be particularly highlighted to their clients upon the first payment certificate, as (Bowles \& Gow, 1992) inform that payments from local authorities at that time were being made for up to $90 \%$ of the value of materials with no knowledge of who held ownership. However, the Regulations and practice by many remained unchanged after the case ruling due to the lack of awareness on the criticality of the subject by many practitioners.

\section{Transformation and Manufactured Goods}

Ownership of materials that have undergone transformation, or have been included within a manufacturing process to become another product entirely, are subject to the specifics of each case in both English and Scots Law. Webb (2000) professes that law courts have 'consistently' maintained that once a transformation has occurred, the original goods are nonexistent and consequently, the claim to title or property for them is 'extinguished'.

An example demonstrating Webb's declaration would be the much referred to English case of Aluminium Industrie Vaassen BV v Romalpha Aluminium [1976] 2 All ER 552 whereby a contract of sale existed between a Dutch Supplier of aluminium foil to an English Purchaser with the intention of using the foil within a manufacturing process. The Purchaser took possession and used a quantity of the foil within the process, however, before providing full payment for the goods the Purchaser became insolvent. The appointed Receiver sold both 
mixed and unmixed materials upon the insolvency and the pursuer argued that ownership had not passed in the goods as full payment had not been received. It was held that title had not passed. However, the unmixed foil that had been sold was now the property of the new buyers and the pursuer could claim the proceeds of the sales. With respect to the mixed goods, Adriaanse (2010) advises they could only reserve title in goods in which they had the title to begin with, the unmixed goods, not the new product.

Palmer (2013) highlight a further demonstration that goods cease to exist due to being irretrievably mixed and transformed within the Scots Law case of Borden (UK) Ltd v. Scottish Timber Products Ltd [1979] 3 WLR 672 in which the retention of title clause was rendered ineffective as the resin supplied had been incorporated into chipboard and was considered to no longer exist.

Conversely, this line of argument was not successful within another Scottish case, that of Armour $v$ Thyssen Edelstahlwerke AG [1989] SLT 182. In this case, Thyssen retained ownership on the basis that title had not passed as the materials had been worked upon, however, they were not irretrievably transformed.

Therefore, in consideration of the foregoing, Hicks (1993) summarises the position of law in either English or Scots Law, on the occasion of transformed goods by stating;

It appears that a seller may effectively retain title...even though minor processes have been performed on the goods, altering their form, but without the addition of further material...where the buyer/manufacturer adds material it is much more likely that the Court will hold that a new species or product has been created.

It is clear from this statement that if small changes have occurred to the goods there may be grounds for retaining ownership, if, however, substantial changes have taken place or other 
goods have been mixed, there is little chance of retaining title as a new product has been made.

\section{Preventative Measures}

Accepted practice in construction is to eliminate or mitigate risks and financial losses which aligns with the sentiments of Vella (2009) who advises that each contractual party should do everything within their power to ensure there is effective security and protection within their transactions to continually reduce their exposure to risk. There are options available to the contractual parties to accommodate for ownership of materials and provide a level of protection for themselves in the event of any party's insolvency whilst maintaining effective management of the project.

A retention of title clause serves the purpose of delaying the transfer of ownership until certain criteria have been fulfilled, namely payment, which Morse (1993) suggests protects the supplier of goods from insolvency of the purchaser. Once materials or goods have been incorporated into the works, a retention of title clause no longer applies. The distinction between Sub-contractor and Supplier is important within the contractual arrangement as a Sub-contractor may present a claim without a retention of title clause, whereas a Supplier may only claim in the event of a retention of title clause. The most secure situation for a Supplier is, as Beale and Mitchell (2009) propose, to refrain from delivery unless full payment has been received or ensure the retention of title clause is applicable. In order for the clause to be effective the direct customer and any third party, such as the Employer, must be aware that a retention of title clause is in operation. As demonstrated within Archivent Sales $v$ Strathclyde Regional Council [1985] a retention of title clause will not protect an unpaid Supplier if the third party purchases the materials in good faith with no prior knowledge of the clause. This, however, can only be effective to an extent, or be subject to conditions, as 
the ruling of Aluminium Industrie Vaassen v Romalpha [1976] established. The intricate nature of construction contracts and the supply chain has enabled a necessity for clauses such as a retention of title to provide a level of assurance and security. Bradgate (1987) believes the main complication is, in fact, the legal systems and their struggle of 'reconciling the several decisions on the subject.'

In order to transfer ownership prior to delivery, the Employer in Scotland may enter into a Contract of Purchase, separate from the main contract which becomes a contract of sale only and, therefore, subject to the Sale of Goods Act 1979. The goods purchased using a contract of this type are omitted from the main contract and the contract sum is adjusted accordingly by deducting the value of the purchased goods informs Frame (2011).

SBCC clause 4.17 facilitates for Contracts of Purchase and explicitly states that should the Contract Administrator or Architect find it 'expedient to do so,' a Contract of Purchase should be entered into for 'any materials and/or goods prior to their delivery to site'. This is in stark contrast to the JCT contract terms in which clause 4.17 'allows the value of off-site materials to be included in the Valuation as long as they have been 'listed' by the Employer' and clause 2.25 which states once the Contractor receives payment from the Employer for listed items 'these materials become the property of the Employer.' The contractual terms illustrate the difference that in English Law, ownership can pass on payment alone within a construction contract, however, in Scots Law, delivery must have taken place for ownership to have passed or a separate contract for the purchase of goods or materials and an omission of the purchase of these items from the construction contract must take place.

According to MacRoberts (2014), Contracts of Purchase are particularly appropriate on occasions where a specialist may require payment for manufacturing or restoring products within his own premises. Some goods in construction are manufactured entirely off site and brought to site for installation or erection only. Steelwork and pre-fabricated forms of 
construction rely upon either; a separate Contract of Purchase and Sale, or the Contractor allows for the financial burden of these items until they are delivered to site and eligible for inclusion in interim payments.

Another option, specific to English Law and JCT standard contracts, is the provision for offsite materials or goods bonds which incorporate a defined schedule of 'listed items' whereby payment for those items is conditional upon transfer of ownership to the Employer. However, MacRoberts (2014) cautions that these terms are not applicable in Scots Law, as it cannot be displayed that title to the materials or goods has indisputably transferred. The Scottish Building Contracts Committee have accommodated for this within their contracts.

As a final option, again specific to English Law, Vesting Certificates are commonly used to transfer the title in materials or goods and provide protection to the owner. Materials and goods are separately identified and securely stored in facilities off site. Struckmeier (2009) warns that Vesting Certificates are not applicable in Scots Law as they will not have the same validity. Evidence of applying English law sentiments within Scotland where they have no jurisdiction or foundation within Scots Law can be found in Sherriff-Substitute Walkers' comment in the case of Stirling County Council v Official Liquidator of John Frame [1951] whereby he remarked the contract condition was in reference to some 'foreign system of law.'

\section{Conclusion}

The legal structure prevalent within Scotland has been established and investigated to determine the nature of construction contracts and subsequently, the conditions applicable to the transfer of ownership of materials in Scots Law. Ownership of goods transfers upon incorporation into the works and delivery as was determined with a degree of finality in the landmark judicial precedent of Stirling County Council v Official Liquidator of John Frame [1951]. Scots Law does not permit transfer of ownership on payment alone, which is contrary 
to practice within England. The crucial concern in paying for materials located off site in Scotland and not obtaining title in them is the risk and impossibility of reimbursement should a Contractor become insolvent. The same can be attributed in the event of a Sub-contractor or Supplier becoming insolvent if the Employer has paid for materials which are not subject to the Sale of Goods Act 1979.

In the construction industry, and indeed in each country where construction operations are taking place, it is imperative that upon entering a contract for construction works that all parties are aware of their responsibilities and entitlements. Attention to the contract conditions and to the prevailing legal structure and current law is essential to fully protect parties against any instances of material ownership dispute which are most likely to arise in instances of insolvency. The transfer and ownership of materials is a topic whereby each occurrence is not documented and instances only become of crucial importance if legal proceedings are raised by a disgruntled party. The complex and intricate nature of the construction industry which trades in high value transactions and investments combined with high instances of insolvencies and disputes in an adversarial atmosphere results in little room for error and it is essential that those involved are fully aware of the legalities surrounding ownership of materials. 


\section{REFERENCES}

\section{Acts of Parliament}

Sale of Goods Act 1979. London: HMSO.

Supply of Goods and Services Act 1982. London: HMSO.

\section{Case Law}

Aluminium Industrie Vaassen BV v Romalpha Aluminium [1976] 2 All ER 552

Archivent Sales \& Development Ltd v Strathclyde Regional Council [1985] SLT 154

Dawber Williamson Roofing Ltd v Humberside County Council [1979] 14 BLR 70

Seath \& Co v Moore [1886] 13 R 57 HL

Stirling County Council v Official Liquidator of John Frame Ltd [1951] SLT 37

Thomas Graham \& Sons Ltd v Glenrothes Development Corporation [1968] SLT 2

\section{Books and Journals}

Adriaanse, J (2010) "Construction Contract Law". 3rd ed. London: Palgrave MacMillan.

Atiyah, P S, Adams, J N \& MacQueen, H (2005) “The Sale of Goods”. 11th ed. Essex: Pearson Longman.

Beale, N \& Mitchell, R (2009) Retention of Title Clauses and s.25 of the Sale of Goods Act 1979.

"Construction Law Journal", 25(7), 498-503.

Bell, G J (1899) "Principles of the Law of Scotland". 10th ed. Edinburgh: T. \& T. Clark.

Bowles, G \& Gow, H (1992) The Position of Materials Re Payment and Ownership in Construction Projects in the UK. In: P. Fenn \& R. Gameson, (eds.) "Construction Conflict, Management and Resolution". London: E \& F N Spon.

Bradgate, J (1987) Reservation of Title Ten Years On. "Conveyancer and Property Lawyer", 434-447. 
Brewer, G (2004) Rights and Remedies - The Ownership of Materials. "Contract Journal", 424(6489), 34.

Connolly, J P (1999) "Construction Law". Edinburgh: W. Green \& Son Ltd.

Frame, S (2011) Working North Of The Border - Key Differences Between JCT and SBCC Contracts. "JCT News", 8-9.

Furmston, M P (2012) "Powell-Smith and Furmston's Building Contract Casebook". 5th ed. Chichester: Wiley-Blackwell.

Furst, S \& Ramsey, S V (2015) "Keating on Construction Contracts". 9th ed. London: Sweet \& Maxwell.

Hicks, A (1993) When Goods Sold Become A New Species. "Journal of Business Law", 485, 485490.

Hughes, W, Champion, R and Murdoch, J (2015) "Construction Contracts Law and Management". 5th ed. London: Taylor \& Francis.

MacQueen, H L \& Thomson, J (2012) "Contract Law in Scotland". 3rd ed. Sussex: Bloomsbury Professional.

MacRoberts (2014) "MacRoberts on Scottish Building Contracts". 3rd ed. Oxford: Blackwell Publishing Ltd.

Malleson, A (2013) National Construction Contracts and Law Survey 2013. "NBS National Construction Contracts and Law Survey 2013", 08-21.

Morse, C (1993) Retention of Title In English Private International Law. "Journal of Business Law", $168-184$.

Struckmeier, A (2009) Off-Site Materials: Out Of Site Shouldn't Mean Out Of Mind. s.l.:Macroberts, Construction Law.

Totty, P, Moss, G \& Segal, N (2014) "Volume II: Part H Miscellaneous: Chapter H6: The Construction Industry In: Insolvency” London: Sweet \& Maxwell.

Uff, J (2013) "Construction Law". 11th ed. London: Sweet \& Maxwell.

Vella, R (2009) Charles Russell Briefing Note: Part III: Ownership of Materials. s.l.:s.n.

Walker, D M (1989) "Principles of Scottish Private Law". 4th ed. Oxford: Oxford University Press.

Watt, K (2010) "SBCC Standard Forms of Building Contract and Insolvency". Edinburgh: Scottish Building Contracts Committee. 
Webb, D (2000) Title and Transformation: Who Owns Manufactured Goods?."Journal of Business Law", 18, 513-540. 